\title{
REINVENTING RURAL FEMININITIES IN THE POST-PRODUCTIVIST FINNISH COUNTRYSIDE
}

\author{
Maarit Sireni ${ }^{1}$
}

Received 1 July 2014; Accepted 25 February 2015

\begin{abstract}
This paper examines how Finnish farm women interpret their own position as women on family farms. Following the poststructuralist approach in rural gender studies, the analysis focuses on the meanings which women produce regarding agrarian femininity. For this purpose, interview material on their everyday life stories are compared with the discourses on rural femininities in the Koti magazine, which is published by the most important organization representing farm women in Finland. It is concluded that the positions in which farm women present themselves are in accordance with the discourses on rural femininity produced and mediated by this magazine. Farm women present themselves, and they are expected to be, economically active agents in the post-productivist countryside.
\end{abstract}

Key words: farm women, gender identity, rural femininity, discourse

\begin{abstract}
Abstrakti: Artikkelissa tarkastellaan, miten suomalaiset maatilan emännät ymmärtävät ja tulkitsevat naisen paikan maatilalla. Tutkimuksen näkökulma on konstruktionistinen. Tavoitteena on tunnistaa maatilan emännyyteen liitettyjä merkityksiä, joita haastatellut naiset tuottavat kuvatessaan jokapäiväistä elämäänsä ja työtänsä maatilalla. Näitä merkityksiä verrataan keskeisen suomalaisen maaseudun naisille suunnatun aikakauslehden tuottamiin maaseudun naiseutta koskeviin puhetapoihin. Artikkeli osoittaa, että naisten esitykset itsestään ovat linjassa heitä koskevien puhetapojen kanssa. He kertovat olevansa ja heidän odotetaan olevan aktiivisia taloudellisia toimijoita postproduktivistisella maaseudulla.
\end{abstract}

Avainsanat: maatilan emännät, sukupuoli, maaseudun naiseus, diskurssi

\section{Introduction}

Since the beginning of the 1980s, there has been a growing scholarly interest in gender issues in rural and agricultural contexts (see Little 2002a; Brandth 2002). An important theme within those agendas has been the position of women on farms. Early work in this area described women's invisible contribution to farm labor (Sachs 1983), whereas more recent research literature has been dominated by a critical-materialistic perspective which has focused on documenting inequalities occurring in agriculture. Central to this critical approach is that

\footnotetext{
${ }^{1}$ Dr. Maarit Sireni, Senior Researcher, Adjunct Professor (Rural Geography), University of Eastern Finland, Karelian Institute, PO. Box 111, FI-80101 Joensuu, Finland, email: maarit.sireni@uef.fi
} 
patriarchal relations on farms are considered as the underlying determinant which structures farm ownership and gender division of labor, and thus defines women's subsidiary role on family farms (Whatmore 1991; Shortall 1992, 1999). According to a comprehensive review by Brandth (2002: 187), inherent in this research strand is that women working in agriculture have not typically been represented as active agents, but more as passive victims who are unable to shape their roles as the wives and mothers of farm successors. As Bryant (1999: 237) has noted, these analysis have left "little room for variation of farm women's identities beyond wifehood".

In the late 1990s, research interests in rural and farm women increasingly turned to become questions of how gender identities - rural femininities and masculinities - are constructed, contested and sometimes reinvented (Little 2002b; Little and Panelli 2003: 281). Within this poststructuralist framework, empirical explorations of farm women have been focused on socially constructed and textually mediated representations of what it means to be a woman in agriculture. Meanings of discursively constructed agrarian femininities have been traced from different textual materials such as policy documents, and rural and agricultural media (Liepins 1996; Brandth and Haugen 1997). Findings of many of these studies suggest that rural media, as well as rural policies and development programs, tend to maintain marginalizing discourses on agrarian femininity in which women are presented as subservient in relation to the needs of the farm and the family (Liepins 2000; Shortall 2002). Therefore, feminist researchers have claimed that dominant discursive practices disempower farm women (Alston 2006).

In an article published in 1999, Oldrup opens the discussion of farm women's identity in order to promote "a more varied and subtle understanding" of the issues at stake. She demands adopting a perspective which would look upon farm women as active and knowledgeable actors who give shape to their lives and construct their identities (Oldrup 1999: 346). The study deals with off-farm working women's self-identities (that is, their senses of self), and Oldrup interprets the identity of a farm woman in the context of late modernity characterized by the twin processes of institutionalization and individualization. The former process refers to the fact that a growing part of our activities are being mediated by institutions such as the welfare state, which potentially have major implications for the conditions under which identities are negotiated. In regard to individualization, Oldrup (1999: 346) means that individuals are increasingly free from traditional bindings such as kin, religion and local community. This is also evident in the case of farm women, who come from different social backgrounds and bring their earlier experiences of work, social relations and family life into their everyday life on the farm. In their daily activities, farm women may also participate in many activities and contexts (both inside and outside agriculture) where they may have different positions and roles. Therefore, it can be assumed that agrarian femininities are indeed more diverse than the former body of the research literature has indicated (Brandth 2002: 182).

Following the seminal contribution by Oldrup (1999), the present article sheds light on what it means to be a woman on a contemporary Finnish family farm. A starting point to this study is the need to bring new perspectives to the view of Finnish agrarian femininities. Previous analyses have suggested that the distinctive physical and cultural contexts of the family farm (which have traditionally favored male successors) continue to determine farm women's everyday life and their understandings of themselves. Within the narrow context of the peasant culture, Finnish farm women have been seen as passive victims who cannot change the fact that they are "just" women in the eyes of those who esteem peasant values and traditions (Silvasti 2003: 154). However, as Oldrup (1999) notes; individuals' understandings of themselves are continual processes which bring together the many life-spheres and experiences of the individual, both inside and outside the farm gates. Therefore, it can be questioned whether peasant values still form the most influential framework which governs the construction of farm women's self-identities in the post-productivist countryside.

Drawing on qualitative interview-material, this paper focuses on analyzing how farm women understand and experience their own situation, and how they construct and represent themselves as farm women. More specifically, the purpose is to unpack discourses through which women produce meanings about agrarian femininity. The focus is on women's own descriptions of their work, social relations and family life. 
Here, it is assumed that individuals are not entirely free to choose the various aspects that make up their identities, but rather that agrarian feminine identities are constructed with relation to predominant culturally-bound discourses on femininities and masculinities which can emerge both inside and outside the agricultural context (Oldrup 1999; Bransholm Pedersen and Kjaergård 2004). These discourses can be competing and offer different truths and contradictory ways of giving meaning to the world. Some however develop as hegemonic discourses and their meanings are adopted as natural and granted truths which have powerful effects on an individual's thinking and behavior. Individual farm women may act in accordance with the subject position that the dominant discourse offers them, but sometimes dominant discourses can invoke resistance if individuals are not comfortable with them (Brandth 2002: 183).

As such, this paper adopts a discursive approach and focuses on the meanings created in language, and attempts to interpret the textual material obtained in the interviews in the light of two relevant discourses concerning femininities in the countryside. Firstly, as family farms cannot be considered as separate entities from the rest of society, the farm women's everyday life stories are interpreted against the well-established backdrop of presenting Finnish women as working mothers who have equal rights with men. However, this does not suggest that equality has been achieved between men and women, or within various groups of women. Rather it is argued that equality is a generally used way of speaking about gender relations in Finland, which amongst other Nordic countries has been characterized as a flagship of gender equality within Europe (Bock 2004: 31). For instance, politicians dealing with equality issues construct gender relations through equality - which paradoxically tends to legitimize the idea that there is no further need to promote equality (Holli 2003). Therefore, the present paper interprets the farm women's stories in relation to the well-established discourse on women as economically active agents, paying attention to the ways how the interviewees' descriptions of themselves reflect on this discourse and whether or not they are comfortable with the subject position which it offers them. For this purpose, the next section of this paper introduces the Finnish version of the welfare state, and also unpacks the cultural expectations of rural and urban women's place in paid employment.

Secondly, the interviewees' descriptions of themselves are compared with current meanings of rural femininities produced by the magazine Koti (Home) which is published by the Rural Women's Advisory Organization (RWAO). The RWAO is the most important organization in Finland representing farm women, and the magazine Koti is the most widely distributed magazine targeted at farm women. The empirical exploration on meanings produced by the magazine Koti, conducted for the purposes of the present paper, is introduced in the third section. The fourth section focuses on the research setting and empirical results of the qualitative study carried out in the eastern Finnish countryside. The paper concludes with a discussion of the findings.

\section{Finnish farm women and the welfare state}

In international comparisons of different welfare state models, Finland has usually been classified as a representative of the Nordic welfare state, which has also been termed as a caring state or a social-democratic type of welfare state (Daly 2001: 45; Asztalos Morell and Bock 2008: 14). Its gender regime has been characterized by the conscious political aim to equalize the roles and status of men and women. Typical to this model is that the social policy is based on individualistic, non-family centered social security, and follows a dual-income family model (Asztalos-Morell and Bock 2008: 13-17). Thus, the dominant gender ideology and practice implies that a woman's place is seen to be in paid employment, and individuals who act differently or against these cultural norms and practices have to explain their deviating choices and life-strategies to other people (Sainsbury 1999; Leira 2002; Bergman 2002). This regime is materialized in the fact that the level of employment among women in Finland is almost as high as that of men (around 70 percent), and in comparison to other EU countries, the difference between male and female employment rates is very low (European Commission 2012).

The development of the welfare state has had several implications both for the socio-economic position and cultural expectations surrounding the roles of women working in agriculture (Sireni 
2008: 38-39). Social security reforms introduced farmers' pensions (1969) and social security, which meant that women have since become entitled to the same benefits as male farmers. In the early 1980s, farm women's rights to maternal leave were also improved and they basically became entitled to the same benefits as women working in other occupations. Currently all families, irrespective of their place of living and parental occupations, have the legal guarantee of public day care for all children under school age (seven years), and these services are relatively cheap, and provided free of charge for low income families. In addition, parents (including farm families) can opt for child homecare allowances for under three-year-old children, instead of using public day care services, and during this time a mother or a father can take leave from work (Ministry of Social Affairs and Health 2013).

The legislation concerning changes of generation and retirement on farms (in-statute since 1974) has been of particular importance for the position of women on farms. Under the current praxis, withdrawing farmers receive financial support, and later a pension, when they hand over ownership and control of their farm to their successor. After this arrangement, the successor who is typically a man - runs the farm without formal interference from the predecessors. In most cases, the two generations live in separate households. Important consequences of this policy regime are that any economic interdependency between the younger and older generations is undermined, and the spouse is provided with an opportunity to buy co-ownership of the farm. Yet, social security and pension are not bound to the farm's co-ownership, but to the individual's agricultural labor input. Women and men active in agriculture are members of the statutory Farmers' Social Insurance Institution to which they pay regular contributions dependent on their personal incomes. In this context the social security of women is personal and they pay taxes separately from their husbands. This implies that women's labor input and the income division between spouses has been made visible by way of the official taxation system. Overall, the fact that a large part of farm families' social relations are mediated by institutions has meant that the status of a farm woman is officially defined in relation to the extended family and her work in agriculture is recognized as a profession. Currently, the inequality between men and women is visible in terms of income: in 2013, an average female farm worker earned $84 \%$ of the income received by an average male counterpart (Mela 2013).

According to some previous investigations on the cultural expectations of rural and farm women's roles in the family, the findings relating to meanings of rurality and femininities in the Finnish countryside deviate from those presented in the main body of rural research literature. The main difference is that they do not support the view that agrarian ideology and discourses have produced romanticized narratives of rural life and women's caring or domestic roles that legitimize the subordination of women (Little and Austin 1996). Furthermore, these studies indicate that there is no single idyllic myth which may dominate people's understandings of the rural woman in the Finnish context. On the contrary, the meanings of rurality which are produced and mediated by media, are plural, complex, fragmental and contain contradictory elements (Malmsten 2000; Alasuutari 2011). Studies on rural women challenge their stereotypical conception as traditional homemakers, and point out that rural women comprise a heterogeneous group of people who work in different occupations and whose employment rate is almost as high that of rural men (Högbacka 2003: 95). Expectations relating to rural women's active participation in the labor market seem to concern farm women as well, and they are expected to have an equal role in comparison to their husbands in earning their living (Sireni 2008: 49). Overall, these previous studies lend empirical support to the view that the family model which consists of two breadwinners is as culturally desirable in the countryside as it is in urban areas.

\section{Women in the RWAO's magazine}

\subsection{Analysis of the Koti magazine}

In order to unpack the current meanings of rural femininities produced by the Rural Women's Advisory Organization (RWAO), two recent volumes of the magazine Koti are analyzed. The RWAO is the most important organization in Finland representing farm women, and was founded in 1930 by establishing specific women's sections in different Farmers' Associations. 
The major aim of its advisory work has been to promote women's contribution to agriculture and to improve their qualification in farm work. More recently it has focused increasingly on the promotion of rural entrepreneurship and multifunctional agriculture. Traditionally, a significant part of the RWAO's advisory activities has also concerned housework such as cooking, handicrafts and gardening, so it has not only supported women's professional roles but also their domestic roles on farms. Although the RWAO represents women, it is usually not seen as feminist organization because it does not problematize the dominant gendered power relations (Bergman 2002). Currently the RWAO has about 55,000 members in its local associations, even though the share of people employed in agriculture has declined to $2 \%$ of the economically active population, and only 84,000 men / 42,000 women work in agriculture (Agricultural Statistics 2011). Since 1939, the RWAO has published its own magazine Koti which is issued ten times a year. According to a recent reader survey it reaches about 40,000 readers in the countryside or in small towns.

The magazine Koti has 47 pages in each issue, and is informative in its orientation, containing the editorial, news on the activities of the RWAO's local associations, and columns and articles on the RWAO's central advisory themes. Of special relevance for this analysis is that Koti also publishes articles on women who describe their daily lives and different types of entrepreneurial activities in the countryside. It is the only magazine in Finland which focuses on rural women's work and family life. In this study, the analysis is based on all 20 issues of Koti magazine issued in the years 2009 and 2010. The empirical material from which the key elements of rural and agrarian femininities are identified consists of 39 articles on rural women, ranging between 25 pages per article.

Discourse analysis has been used as a main approach to the texts. The stories depicted in the magazine can be seen as reflecting the RWAO's view on what is "a woman's place" in rural families and communities. Not all of the contents of the magazine can however be understood as a considered view of the organization, as the magazine is also an important channel which mediates women's ideas of being a woman in the countryside among rural women themselves. Therefore, it can be argued that the magazine both produces and mediates meanings of rural femininity (see Liepins 1996: 5; Brandth and Haugen 1997: 330). In this study, attention is paid to both of these two voices which can be identified in the texts.

\subsection{Rural women's portraits in the Koti magazine}

The rural women featured in the articles of the Koti magazine typically conduct part-time or fulltime entrepreneurial activities in semi-rural and rural areas. The spectrum of the occupations is wide, including a full-time female farmer, a riding therapist, a dog breeder, a joiner, a cosmetologist, a care service entrepreneur, a forest farmer, a forest harvesting entrepreneur, and different types of artisans, quality food producers and rural/nature tourism operators. What is noteworthy here is that Koti gives much exposure to those women who work in other rural sectors than those engaged in farming. This emphasis is in line with the RWAO's current advisory agenda, which highlights the role of empowered women as engines of a new rural economy. Therefore, this selection of interviewees can be interpreted as an outcome of the magazine's conscious editorial policy. The RWAO keenly portrays rural women as a heterogeneous group of individuals who run new businesses in the post-productivist countryside.

Not surprisingly, the women's stories depicted in the magazine are decidedly positive and encouraging. The RWAO constructs an image of rural women as active, innovative, determined and capable actors who define their own way of life. A representative piece focuses on a woman running a business, starting from the invention of their idea which has developed and matured and turned out to be successful. A common element in these success stories is that the women are presented as being devoted to their businesses, whereas their families and household duties play a secondary role. Thus, although the magazine provides its readers with a richness of cooking and baking recipes, all of the interviewed women are presented in professional roles, as fully authorized entrepreneurs or business partners. In many cases, a man plays a secondary role and is described as a helping hand for his wife, perhaps 
contributing to the business during high season or taking care of the children when the woman's irregular working hours do not coincide with the opening hours of the kindergartens.

Heidi, 33, is one of the full-time female farmers who are interviewed in the magazine. She is married to Pekka, and they have three young children. Both Heidi and Pekka have a college degree in agriculture, and are business partners on a co-owned dairy farm which has belonged to Pekka's family since 1697. The husband's grandfather lives in the same household and takes care of their children, as Heidi devotes herself to the farming business which has developed to become a large-scale activity. In the interview, Heidi emphasizes their massive investments on a new cowshed and a milking robot, and thus makes it clear that she is a well-educated farmer who actively participates in agricultural decision-making. There are no elements in the interview (or hints which could be read between the lines) which would suggest that Heidi is considered (or considers herself) as being subordinate to the needs of the farm and family. She does not work in agriculture in order to ensure that her husband can continue to farm, but rather because she is herself a professional co-owner of the farm.

Another example of a full-time female farmer is middle-aged Maire, who grows and sells timber to forest companies and firewood to private consumers. Maire is a single mother of three daughters, whose strength as a woman and expertise as a forest farmer are highlighted in the article. She characterizes herself as an open-minded person who is anxious to learn more about forestry. A common element to these two articles is that the men's and women's roles on farms and in rural communities are not explicitly discussed. Rather, the key message seems to be that being a farm woman implies similar possibilities and responsibilities as being a farm man.

The articles about women involved in businesses other than agriculture, celebrate their creativeness and innovativeness as rural entrepreneurs. According to the headlines, the enterprises "keep on rolling" and the women "actualize their dreams". However, the women interviewed, such as Johanna who produces children's clothing and ecological diapers, tend to give a more pragmatic picture of a small-scale entrepreneur's everyday life, which entails a lot of work without proper holidays. Johanna wanted to take care of their three children at home while working, but this turned out to be impossible as the enterprise demanded full-time involvement in the business. Therefore, she has had no other choice than to take her children to a public kindergarten. In the article Johanna says that her "heart is bleeding" and she is very disappointed with the fact that she does not have much time for her children. During busy periods, Johanna's husband Matti has been responsible for child care and undertaking household tasks in the evenings.

The disappointment expressed by Johanna is not quite in line with the RWAO's current agenda which pushes women to find new niches and to create successful businesses. Therefore, it is understandable that negative comments which would challenge the RWAO's views are not given much exposure in the magazine. Another example of a rural woman whose story is out of tune with the magazine's encouraging headlines is Heidi, 25 , who runs a web store. She gives the impression that her free time remains scarce, and refers to her low income by telling that her earnings consist of "tiny pieces".

Overall, there are two main discourses on rural femininity which the RWAO actively promotes on the pages of Koti magazine. Firstly, rural women are presented in accordance with the more general discourse on Finnish women's economic independence - as active economic agents and subjects in their own lives. All of the rural and farm women interviewed in the magazine share this view, and take women's active participation in the labor market as a for granted element of being a woman in the countryside. Secondly, the RWAO attempts to construct rural women as successful entrepreneurs and engines of the new rural economy. This discourse of success however is challenged by some women, whose critical comments raise doubts that the RWAO tries to draw a too positive picture of women's economic activities in the countryside. Clearly not all ordinary rural women are comfortable with the demands for success and the subject position as a successful entrepreneur, which the current discourse offers them. 


\section{Farm women's self-identities}

\subsection{Analysis of the theme interviews}

The theme interviews of farm women were conducted in two phases in three rural municipalities in the region of North Karelia in the eastern part of Finland. In the first phase, 15 women were interviewed, selected on the basis of quantitative background data collected from the official tax reports from all the farms within the study region. This sample consisted of different types of farms and families. In the second phase (three years later), five of the women were interviewed for a second time. They were selected so that the smaller sample included farm women with different social backgrounds and main sources of income. In line with general trends in Finland, many of the interviewees do not come from the local area or have a farming background, and all of the women in the sample were newcomers to farms. They lived on different types of farms which are all relatively small and typical of the region in general. The biographical details of the women interviewed twice are presented in Table 1. In order to protect their anonymity their names have been changed here.

Mari and Sarita represent young women with rural backgrounds. Mari is well-educated, whereas Sarita used to work as a municipality-paid holiday replacement for farmers before she became the co-owner of a farm. When Mari was interviewed for the first time, she was on maternal leave from her off-farm work as a social worker. In the second interview, she received child homecare allowance and worked occasionally to help her husband who owns the farm. Mari is an atypical farm woman in the sense that she has taken a university degree, although farm women tend to have higher educational qualifications than their husbands (Sireni 2008: 44). Locally born Minna is the co-owner of a dairy farm and has worked full-time in agriculture since she married right after school. Liisa has a farming background, but she has also lived in a town and had several blue-collar occupations before her (second) marriage. Since then, she has worked full-time on the co-owned farm together with her husband. Pirjo comes from an urban background. She used to work on the co-owned farm, but since finishing her studies she has worked as a nurse at the local health-care center.

\begin{tabular}{|l|l|l|l|l|l|l|l|l|}
\hline & Background & Education & $\begin{array}{l}\text { Number } \\
\text { of } \\
\text { children }\end{array}$ & $\begin{array}{l}\text { Age at the } \\
\text { time of the } \\
\text { interviews }\end{array}$ & $\begin{array}{l}\text { Husband's } \\
\text { occupation }\end{array}$ & $\begin{array}{l}\text { Woman's } \\
\text { share of } \\
\text { the farm }\end{array}$ & $\begin{array}{l}\text { Farm size } \\
\text { and type }\end{array}$ & $\begin{array}{l}\text { Main source of } \\
\text { income at the time } \\
\text { of the interviews }\end{array}$ \\
\hline Mari & $\begin{array}{l}\text { fural, } \\
\text { middle- } \\
\text { class, not } \\
\text { locally born }\end{array}$ & $\begin{array}{l}\text { university } \\
\text { degree in } \\
\text { social } \\
\text { sciences }\end{array}$ & 2 & $30 / 33$ & Farmer & $\begin{array}{l}\text { not a } \\
\text { co-owner }\end{array}$ & $\begin{array}{l}25 \text { ha } \\
\text { field, dairy } \\
\text { and } \\
\text { forestry }\end{array}$ & $\begin{array}{l}\text { maternal leave } \\
\text { benefit (off-farm } \\
\text { job)/ child } \\
\text { homecare } \\
\text { allowance }\end{array}$ \\
\hline Sarita & $\begin{array}{l}\text { rural, } \\
\text { working } \\
\text { class, locally } \\
\text { born }\end{array}$ & $\begin{array}{l}\text { vocational } \\
\text { training in } \\
\text { agriculture }\end{array}$ & 3 & $31 / 34$ & Farmer & 50 percent & $\begin{array}{l}22 \text { ha } \\
\text { field, dairy } \\
\text { and } \\
\text { forestry }\end{array}$ & $\begin{array}{l}\text { maternal leave } \\
\text { benefit } \\
\text { (agriculture)/ child } \\
\text { homecare } \\
\text { allowance } \\
\text { (agriculture) }\end{array}$ \\
\hline Minna & $\begin{array}{l}\text { rural, } \\
\text { middle- } \\
\text { class, locally } \\
\text { born }\end{array}$ & $\begin{array}{l}\text { no } \\
\text { education } \\
\text { courses in } \\
\text { agriculture }\end{array}$ & 5 & $32 / 35$ & $\begin{array}{l}\text { Farmer } \\
\text { (pluriactive) }\end{array}$ & 50 percent & $\begin{array}{l}42 \text { ha } \\
\text { field, dairy, } \\
\text { grain and } \\
\text { forestry }\end{array}$ & $\begin{array}{l}\text { child homecare } \\
\text { allowance } \\
\text { (agriculture)/ } \\
\text { agriculture }\end{array}$ \\
\hline Liisa & $\begin{array}{l}\text { rural, } \\
\text { agricultural, } \\
\text { not locally } \\
\text { born }\end{array}$ & $\begin{array}{l}\text { vocational } \\
\text { training in } \\
\text { agriculture }\end{array}$ & 1 & $43 / 46$ & Farmer & 50 percent & $\begin{array}{l}17 \text { ha } \\
\text { field, dairy } \\
\text { and } \\
\text { forestry }\end{array}$ & $\begin{array}{l}\text { agriculture/ } \\
\text { agriculture }\end{array}$ \\
\hline Pirjo & $\begin{array}{l}\text { urban, } \\
\text { working } \\
\text { class, not } \\
\text { locally born }\end{array}$ & nurse & 2 & $34 / 37$ & $\begin{array}{l}\text { Farmer, } \\
\text { (pluriactive) }\end{array}$ & 50 percent & $\begin{array}{l}20 \text { ha } \\
\text { field, meat } \\
\text { and } \\
\text { forestry }\end{array}$ & $\begin{array}{l}\text { agriculture } \\
\text { (student)/ off-farm } \\
\text { job }\end{array}$ \\
\hline
\end{tabular}

Tab 1. The background of the interviewed women.

The interviews focused on women's life histories and their everyday life experiences as farm women, on themes related to work, farming, family, free-time activities and social relations. In the analysis of the interviews, discourse analysis was used as a main guideline, and identity has 
been understood as being context-dependent, produced in social relations and in interaction with others. This implies that a person has no singular or constant idea of the self, but rather that the idea is constantly reworked in different social situations. Here, the representations of the interviewed women are not seen as reflections of reality, but are understood as part of the social action and the construction of social reality (Wetherell and Potter 1988). Therefore, the focus of the analysis is placed on ways in which the women describe and simultaneously construct their lives as farm women.

In the following examples, women's identities are analyzed according to three themes, which reflect the dominant issues in the narratives of their lives as farm women. The first includes various episodes concerning a woman's move to a farm and her relations with her husband's parents, that is, the preceding farming couple on the same farm. The second key theme in the interviews deals with the construction of a woman's identity in relation to farm work, that is, an interviewee ponders over the reasons for the prevailing gender division of labor on the farm, her own professional identity, and the changing role of domesticity in her life. The third theme centers on a woman's relations with other farm women she knows in the local community or elsewhere. Here, the interviewees elaborate upon similarities or dissimilarities with respect to their counterparts.

\subsection{A move to a farm: the discourse of activeness}

As previously mentioned, farm successors tend to be men and this is inconsistent with the general ideals of gender equality. When the interviewed women were asked about their experiences of their position as a farm successor's wife, their descriptions of themselves as newcomers included some shared ways of dealing with the issue. Here, the dominant approach is named as the discourse of activeness due to the fact that the narratives of each interviewed woman depicted a woman as an active initiator, both in the relationship and her arrival on the farm. In some accounts, such as Minna's, the desire to become a farmer was explicitly mentioned. Sarita's description of her arrival on her husband's farm contains several elements of activeness:

\section{Interviewer: What were your plans for the future when you were young?}

Minna: I have always dreamt about being a farmer, because in this occupation you can be your own boss. I am such a person who needs to be independent in her work. Besides, I like animals, especially cows. As a child, I was envious of those friends who lived on a farm and had cows and cats. Thus, I felt I was lucky as Ilkka (her husband) happened to be a farmer's son.

Interviewer: Do you remember the day when you moved here?

Sarita: I went to the same school as my current spouse, but we did not become more closely acquainted with each other until later when I worked as a municipality-paid holiday replacement for farmers on a neighboring farm on the other side of the lake. He came to see me there. Two weeks later, I gathered my belongings and came by motorboat to this farm. He was a bit surprised when I told him to carry the luggage, as I was going to move here. The man did that, three months later we got engaged, and our first child was born 10 months later.

Even if these women were newcomers to farms which had in some cases belonged to the same family for generations, they did not refer to the problems of adjustment caused by this mental tradition. Rather, they tended to see the problems in very pragmatic terms; describing a family farm as an old-fashioned place to live, without the facilities which they used to have in the past. For this reason, repairs to buildings played a major role in the interviewees' accounts in relation to their settling down on the farm. The remodeling of buildings also seems to have symbolic value due to the fact that it represents their taking over the occupation of the living space from the earlier generation. Again, women constructed an image of themselves as active agents in the adjustment process:

Interviewer: Did you have any problems of adjustment?

Pirjo: We took over this farm when I had just given birth to our first child. We moved here from the city when my mother-in-law retired and moved away. I remember it was a terrible winter; the temperature was down to minus 32 centigrade (Celsius) for seven weeks - I was freezing. 
We had virtually no conveniences, a small baby and a lot of washing. But I am not a person who gets frightened easily. After some years we built this new house.

Interviewer: How did it go when you moved here?

Mari: We lived in the same house (with her husband's parents) during the first year of my stay here, and it often made me mad. I feel very happy to live in a separate household now. However, my husband's parents would like to see more things in common; they do not like our way of doing things in our own way. I am aware of the fact that the parents-in-law tend to see my way of life as arrogant.

Interviewer: Did you do some things in a different way in comparison to your mother-in-law?

Liisa: Yes, my mother-in-law felt uncertain whether she can learn my ways of doing things. I said to her that I will close my eyes - let's both stick to our own styles. So, it did not actually bother me.

The interviewed women, such as Liisa and Mari, made it clear that in conflict situations the older generation had been compelled to admit that control over the farm has been irrevocably transferred to the younger farmers. According to the interpretations of the interviewees, this shift was quite clear-cut. Consequently, they described themselves as capable of defining their own ways of being farm women. An important institutional reason for the empowerment of a newcomer is the ownership structure, so that the change of generation on the farm is organized in a clearly defined way. Given this, it is only natural that a newcomer may well arrange her own living space according to her own preferences - something which was not possible in the peasant culture prevailing in Finland in the past (Siiskonen 1990; Apo 1993; Östman 2000).

\subsection{Farm work and child care: the discourse of conscious choice}

The division of labor on farms, and women's experiences of off-farm work were central topics discussed in the themed interviews. As most of the women had young children, issues related to care were significant in their narratives. It came out in the interviews that in spite of the general expectations surrounding women's roles as working mothers, the division of labor is gendered in young farm families: it is the women who concentrate on taking care of small children. The women's ways of talking about child care were similar to each other in the sense that they presented the gendered division of labor in this respect as being their own choice. Here, this way of explaining the division of labor is termed as the discourse of conscious choice.

For instance, Mari (who has permanent off-farm work but who was temporarily off duty and received child home care allowance as she had children under three years) admitted that their division of labor in agricultural and domestic work was not in-line with general ideals of gender equality. However, Mari emphasized that she was not motivated to participate in farming activities for the reason that her aim was not to become a professional farmer. She had other work to which she will return in a few years, and therefore she did not see any major problems in her current role as the "farmer's helping hand":

Interviewer: How do you and your husband share the work?

Mari: I have had a clear-cut division of labor with my husband. I focus on the children, and he takes responsibility for the farming business. I am also happy that I managed to complete my studies in the university and even get a permanent job before the first baby was born. Now I can stay at home without such worries - at least three years for the time being.

It is worth emphasizing here that even if the interviewees give positive representations of motherhood, they tend to present themselves primarily in other roles which are seen as culturally more legitimate: as off-farm working women, professional farmers, or students. This also seems to be related to the family situation and social benefits. As soon as children reach the age of three and families stop receiving child homecare allowance, a woman tends to become increasingly interested in her occupational identity, and is inclined to redefine her role and place on the farm. At this new stage of life, it is the husband's turn to take care of the children. In this vein, the well-educated Mari and Pirjo made clear their orientation towards 
off-farm labor markets, and stressed their professional ambitions. In the interviews, both of them related many episodes in which they constructed an image of themselves as off-farm working women, who helped their husbands of their own free will. For Pirjo - whose husband has stayed at home taking care of their son (as the child did not feel comfortable at a public kindergarten) farming is currently just physical exercise, which she finds enjoyable:

Interviewer: Do you participate in farm work nowadays?

Pirjo: Yes, sometimes I change my white (nurse's) dress to rags. I really enjoy physical work and sweating.

However, not all farm women have such educational qualifications that they can find an off-farm job more or less on demand. In the presented data, the disparities among the respondents were clearly illustrated. The two interviews of Minna do not provide a completely coherent picture about her identity as a farm woman. In the first interview, she described herself as a full-time farmer and mother who was devoted to dairy farming and her family. However, in the second interview, Minna emphasized that she had sought further occupational training. Although she had worked on a farm throughout her life and looked after children, she also wanted to represent herself as a socially and culturally acceptable woman, who continues her career after a spell at home during a certain stage of life. She described herself as a former promising high school student who still had several prospects in life available:

Minna: I got married and settled down on this farm right after high school. My grandfather, among others, was disappointed, saying that my good scores at school are wasted when I am not going to continue my studies.

Liisa, for whom gaining an educational degree was not any more a relevant option due to her age, described her activities in the development of dairy farming and forestry. She presented herself as a more innovative farmer than her husband and also stressed her achievements in everyday agricultural work. In the interview, her husband Pentti (who was present at the time) did not disagree with this view. In the coffee table discussion (dominated by two women), he was inclined to support socially acceptable views, demonstrating that he was not a traditionbound relic from the backwoods, but a normal man who treats his wife as an equal partner. A similar qualification applies to Minna's husband Ilkka, who also discussed issues at the coffee table after the interview. They both presented themselves as caring men, who shouldered their proper responsibilities for domestic work:

Liisa: In dairy farming, when you do your job well, you have the possibility to see concrete good results.

Liisa's husband Pentti, referring to Liisa: I have seen your good ideas on the business - that is the reason why I asked you for advice on the cow shed.

Minna's husband Ilkka: I have not wanted to increase the amount of cattle for the reason that I want to spend some time with my children too. Besides, as we live here in the countryside where distances are long, my labor input is needed as the children's chauffeur - they have a lot of hobbies.

Of the women interviewed, Sarita felt uncertain about what to do when her children go to school. In the first interview she was anxious to learn more about cattle breeding, whereas three years later she was disappointed both in their cows (because of their low productivity) and her role as a farm woman, arguing that she did not have sufficient skills to do all the farming tasks, and thus she did not meet the expectations that are faced by farm women. Sarita participates in, for instance, agricultural work in the fields, but reported her skills as being deficient, although she would like to play an equal role with her spouse in farming work:

Sarita: I am not happy with what my role is in practice; I would like to take a more independent role, and do any work available.

Interviewer: But I saw you driving a tractor when I arrived... 
Sarita: That was routine. See, I do not know how to shift devices such as ploughs. I have not yet learnt them - when the kids were small, my husband did all those tasks. But I would like to do them, properly and correctly.

In the interview, Sarita did not report any clearly formulated plan of how she would be able to rescript her role in a new situation. She had no possibility to return to her earlier job as a farmer's replacement by reason of the fact that municipalities cut public expenditure and thus no-longer recruit workers. On the other hand, it is not certain whether she will be able to reach an equal standing in the agricultural division of labor with her husband. In more general terms, this episode gives an example of how focusing on motherhood is seen as socially acceptable, albeit as a temporary arrangement. Farm women seem to be well aware of the general expectations concerning their roles as active agents and as breadwinners alongside their husbands.

\subsection{Free time and social relations: the discourse of individualism}

Irrespective of the fact that the interviewed women worked in farming on at least a part-time basis, most of them did not identify themselves as "real" farm women. Typically, an interviewee characterizes a real farm woman in some detail, and also explains how she feels different. To a remarkable degree, these caricatures resemble the description by Brandth (2002) of a subordinated farm woman in the context of the critical-materialistic perspective which dominates the research literature. The interviewees made it clear that they do not fit into that model, and characterized their distinctiveness in several ways. Thus, the discourse of individualism (as it is called here) consists of several elements. Firstly, the women reported small episodes of how they are independent from the relatives of their spouses. Secondly, they argued that they have had the freedom to choose their professions, and in particular this concerns the choice of whether they work on or off the farm. The third main difference was presented in relation to free-time and social relations: the interviewed women argued that they can have any hobbies they like and they can well define a lifestyle of their own. It is especially noteworthy that this choice was also seen to include matters of housework to which they can have different approaches.

In summary, all of the interviewed women saw major differences between themselves and those who they called real farm women in their social life and free-time activities. They described themselves as individuals, who have interests of their own which do not necessarily benefit the survival of the family farm. Mari stressed her freedom to choose her profession, and presented herself as independent from the extended farm family. Minna and Sarita presented themselves as individuals, who did not have to ask money from their husbands. Sarita for the main part stressed that she has kept her hobby as a dog breeder, although it often requires travelling at weekends - which implies that at such times, her husband has to manage alone with the cattle and their (three) children. Pirjo referred to her urban background and to social relations beyond the local community when she constructed differences between real farm women and herself. Also, Liisa constructed her distinctiveness by telling stories about her previous life in a town where she had worked in several male-dominated occupations before her marriage with a farmer:

Interviewer: Did you face any prejudices when you moved here?

Liisa: I am different; I used to live in town and worked in occupations which are not typical for women - as a lorry-driver and as a construction worker. This was something new in this village and gave rise to prejudices.

Interviewer: Are you a typical farm woman?

Sarita: I am different from the farm women of the good old times; I have got money and my free time activities are not dictated by anybody. Some locals seem to be envious of the idea that I can drive independently to anywhere for my hobbies at weekends. In the past, a farm woman had no such possibilities.

Interviewer: What are the main differences between you and farm women of the past? 
Minna: As the only way to earn some money of their own, farm women of the previous generation had to pick berries and mushrooms for sale. This is not at all common any more as all farm women have money of their own.

Overall, common to all women interviewed is their experience of difference: the interviewees made a clear-cut distinction between themselves and those who represent to them "real farm women". Specific arguments obviously differ according to personal histories and experiences: one interviewee emphasizes her educational background, another pays attention to her career, and so on. In any case, the common argument is that the interviewees described themselves as individuals, who do not fit into the category of real farm women who were assumed to be homogenous. In other words, the women described real farm women as unable to reflect, transform and reconstruct their identities, whereas they presented themselves as active agents, and shapers of their own lives and identities.

\section{Conclusion}

Drawing on the qualitative interview material, this paper analyzes how Finnish farm women experience their position as women on family farms. Following the poststructuralist approach in rural gender studies, it attempts to unpack the discourses through which women produce meanings about agrarian femininity. As individuals are presumed to construct their gendered self-identities in relation to hegemonic discourses concerning femininities and masculinities in specific socio-cultural contexts, the interviewees' descriptions of their everyday lives are interpreted in relation to the dominant discourse concerning gender relations in Finnish families. This suggests that there are two breadwinners in families, and that mothers should be active agents in the labor market (e.g. Bergman 2002). In order to shed light on the specific expectations surrounding women's roles in rural families, this paper investigates the meanings of rural and agrarian femininities produced by the leading farm women's organization in Finland, the RWAO. The socially constructed and textually mediated representations of what it means to be a rural woman are identified from two volumes of the magazine Koti published by the RWAO.

The central finding concerning the discourses on rural femininity which Koti magazine produces and mediates, is that they are well in-line with the prevalent idea of Finnish women as economically active agents. Firstly, readers of Koti magazine are told that farm women and female rural entrepreneurs are devoted to their careers and work. This orientation towards a career outside the home is taken as both natural and for granted by those rural women who are interviewed in the magazine. Secondly, the magazine underlines women's crucial role as engines of the new rural economy and promotes a discourse which celebrates women's roles as successful entrepreneurs in the countryside. Rural women are presented as actualizing their dreams and their small-scale businesses are said to be flourishing. This discourse is however, challenged by some (few) critical women who are given voice in the magazine. Not all female rural entrepreneurs are comfortable with the position which the discourse offers them as successful entrepreneurs, and some women express that they would actually like to have less work and more time for their children.

The everyday life stories of the farm women who were interviewed in eastern part of Finland, support the finding that ordinary farm women have not wholly adopted the discourse of success, as promoted by the Koti magazine. In their case, the fact that they live on conventional cattle farms (which can be considered as standard) explains to a large degree the absence of references to new business options in the post-productivist countryside. What is clear is that all of the interviewed farm women speak about themselves in accordance with the subject position that the other central discourse offers them - as economically active agents. The interviewees seem to be well aware of the expectations concerning the dual-income family model that is the prevailing norm in the context of the Nordic welfare state. As an indication of this, each of the interviewees presents herself in a role which is culturally legitimate: as an off-farm working woman, a professional farmer, or as a student. All of the interviewees' stories about themselves include elements of activeness, initiative and independence when they describe their work and family life on the farm. What is also common, is the experienced difference in their relation to previous generations of farm women, whose possibilities to choose their roles and shape their identities are presumed to have been limited. To underline the changes in a woman's position 
on a farm, the interviewees constructed an image of themselves as knowledgeable agents of their lives, who are capable of shaping and defining their own ways of being farm women.

To conclude, in this specific material and discursive context, which strongly supports and stimulates female employment, and reproduces an image of rural women as active agents; it would be socially and culturally unbearable to talk about oneself as being subservient to the needs of the farm and the (extended) farm family. Therefore, it is understandable that the women's stories about themselves do not contain such elements. Behaving against general expectations would be socially and culturally dubious as well. As women's active participation in the labor market is both the general ideal and norm, and the Koti magazine celebrates the numerous options which are open for women, an individual woman who would work on her husband's farm as an unpaid helping hand would probably not meet with much understanding amongst other people. It can therefore be argued that Finnish farm women living and working in the post-productivist countryside are expected to act out success stories - not victim stories.

References

[1] Agricultural Statistics (2011). Number of people employed in agriculture in Finland is currently $30 \%$ fewer than in 2000, Available: http://www.maataloustilastot.fi/en/node/2201.htm (accessed 28 October 2013).

[2] Alasuutari, P. (2011). Mielikuvien muutos ja pysyvyys. Maaseutukäsite suomalaislehdissä 2000-luvulla, Maaseudun uusi aika, vol. 19, no. 1, pp. 17-32.

[3] Alston, M. (2006). "I'd like to just walk out of here": Australian women's experience of drought, Sociologia Ruralis 46(2), 154-170. DOI: 10.1111/j.1467-9523.2006.00409.x.

[4] Apo, S. (1993). Orjatyöstä oman kodin valtiaaksi. Näkemyksiä kahdeksasta maalaiselämän kuvauksesta (pp. 125-148). In Piela, U., ed., Aikanaisia. Kirjoituksia naisten omaelämäkerroista, Helsinki: SKS.

[5] Asztalos Morell, I. \& Bock, B. (2008). Rural gender regimes: The development of rural gender research and design of a comparative approach (pp. 3-30). In Asztalos Morell, I. \& Bock, B., ed., Gender regimes, citizen participation and rural restructuring, Oxford: Elsevier.

[6] Bergman, S. (2002). The politics of feminism. Autonomous feminist movements in Finland and West Germany from the 1960s to the 1980s, Åbo: Åbo Akademis förlag.

[7] Bock, B. (2004). It still matters where you live: Rural women's employment throughout Europe (pp. 14-41). In Buller, H. \& Hoggart, K., eds., Women in the European countryside, Aldershot: Ashgate.

[8] Brandth, B. (2002). Gender identity in European family farming: A literature review. Sociologia Ruralis, 42(3), 181-200. DOI: 10.1111/1467-9523.00210.

[9] Brandth, B. \& Haugen, M. (1997). Rural women, feminism and the politics of identity, Sociologia Ruralis, 37(3), 325-344. DOI: 10.1111/j.1467-9523.1997.tb00054.x.

[10] Bransholm Pedersen, K. \& Kjærgård, B. (2004). Do we have room for shining eyes and cows as comrades? Gender perspectives on organic farming in Denmark, Sociologia Ruralis, 44(4), 373-394. DOI: 10.1111/j.1467-9523.2004.00282.x.

[11] Bryant, L. (1999). The detraditionalization of occupational identities in farming in South Australia, Sociologia Ruralis, 39(2), 236-261. DOI: 10.1111/1467-9523.00104.

[12] Daly, M. (2001). Caring policies in Western Europe (pp. 33-56). In Daly, M., ed., Care work. The quest for security, Genova: International Labour Office.

[13] European Commission (2012). Eurostat, Employment statistics, Available: http://epp.eurostat.ec.europa.eu/statistics_explained/index.php/Employment_statistics.htm (accessed 18 December 2013). 
[14] Holli, A. (2003). Discourse and politics for gender equality in late twentieth century Finland, Helsinki: Helsinki University Press.

[15] Högbacka, R. (2004). Naisten muuttuvat elämänmuodot maaseudulla, Helsinki: SKS.

[16] Leira, A. (2002). Working parents and the welfare state. Family change and policy reform in Scandinavia, Cambridge: Cambridge University Press.

[17] Liepins, R. (1996). Reading agricultural power. Media as sites and processes in the construction of meaning, New Zealand Geographer, 52(2), 3-10. DOI: 10.1111/j.17457939.1996.tb02060.x.

[18] Liepins, R. (2000). Making men: The construction and representation of agriculture-based masculinities in Australia and New Zealand, Rural Sociology, 65(4), 605-620. DOI: 10.1111/j.1549-0831.2000.tb00046.x.

[19] Little, J. (2002a). Gender and rural geography. Identity, sexuality and power in the countryside, Harlow: Prentice Hall.

[20] Little, J. (2002b). Rural geography: rural gender identity and the performance of masculinity and femininity in the countryside, Progress in Human Geography, 26(5), 665-670. DOI: 10.1191/0309132502ph394pr.

[21] Little, J. \& Austin, P. (1996). Women and the rural idyll, Journal of Rural Studies, 12(2), 101-111. DOI:10.1016/0743-0167(96)00004-6.

[22] Little, J. \& Panelli, R. (2003). Gender research in rural geography, Gender, Place and Culture, 10(3), 281-289. DOI:10.1080/0966369032000114046.

[23] Malmsten, J. (2000). Maaseutu mediassa, Maaseudun uusi aika, vol. 8, 5-19.

[24] Mela (Maatalousyrittäjien eläkelaitos) (2013), Available: http://asp.hci.fi/mela/tilastot.nsf/Kuntatilastot_Vakuutukset?OpenView\&kunta=607\&vertailu $=$ M\&tyyppi=U. htm (accessed 17 January 2014).

[25] Ministry of Social Affairs and Health (2013). Social and health services. Financial assistance for families with children, Available:

http://www.stm.fi/en/income_security/financial_assistance_families.htm (accessed 17 January 2014).

[26] Oldrup, H. (1999). Women working off the farm: Reconstructing gender indentity in Danish agriculture, Sociologia Ruralis, 39(3), 343-358. DOI: 10.1111/1467-9523.00112.

[27] Östman, A. (2000). Mjölk och jord. Om kvinlighet, manlighet och arbete I ett Österbottniskt jordbrukssamhälle ca 1870-1940, Åbo: Åbo Akademis förlag.

[28] Sachs, C. E. (1983). The invisible farmers: Women in agricultural production, Totowa: Rowman \& Allanheld.

[29] Sainsbury, D. (1999). Gender and Welfare State Regimes, Oxford: Oxford University Press.

[30] Shortall, S. (1992). Power analysis and farm wives: An empirical study of power relations affecting women on Irish farms, Sociologia Ruralis, 32(4), 431-451. DOI: 10.1111/j.14679523.1992.tb00941.x.

[31] Shortall, S. (1999). Women and farming. Property and power, Houndmills: Macmillan.

[32] Shortall, S. (2002). Gendered agricultural and rural restructuring: A case study of Northern Ireland, Sociologia Ruralis, 42(2), 160-175. DOI: 10.1111/1467-9523.00208.

[33] Siiskonen, P. (1990). Emännän ja isännän roolin muutos maatalouden uudenaikaistuessa. Tutkimus maatilan emännän ja isännän muuttuvista rooleista työnjaon avulla tarkasteltuna, Mikkeli: University of Helsinki.

[34] Silvasti, T. (2003). Bending borders of gendered labour division on farms: The case of Finland, Sociologia Ruralis, 43(2), 154-166. DOI: 10.1111/1467-9523.00236. 
[35] Sireni, M. (2008). Agrarian femininity in a state of flux: Multiple roles of Finnish farm women (pp. 33-55). In Asztalos Morell, I. \& Bock, B. (ed.) Gender regimes, citizen participation and rural restructuring, Oxford: Elsevier.

[36] Whatmore, S. (1991). Life cycle or patriarchy? Gender divisions in family farming, Journal of Rural Studies, 7(1-2), 71-76. DOI:10.1016/0743-0167(91)90043-R. 